\begin{tabular}{|c|c|}
\hline Title & $\begin{array}{l}\text { A novel mechanism for imatinib mesylate (STI571) resistance in CML cell line KT-1 : Role of TC- } \\
\text { PTP in modulating signals downstream from the BCR-ABL fusion protein. }\end{array}$ \\
\hline Sub Title & $\begin{array}{l}\text { 慢性骨髄性白血病細胞株KT-1における新たなイマチニブ(STI571)耐性化の機構 : BCR- } \\
\text { ABL融合蛋白下流のシグナル伝達を修飾するTC-PTPの役割 }\end{array}$ \\
\hline Author & 清水，孝恒(Shimizu，Takatsune) \\
\hline Publisher & 慶應医学会 \\
\hline Publication year & 2005 \\
\hline Jtitle & 慶應医学 (Journal of the Keio Medical Society). Vol.82, No.2 (2005. 6) ,p.16- \\
\hline \multicolumn{2}{|r|}{ ( } \\
\hline \multicolumn{2}{|l|}{ Abstract } \\
\hline Notes & 号外 \\
\hline Genre & Journal Article \\
\hline URL & $\begin{array}{l}\text { https://koara.lib.keio.ac.jp/xoonips/modules/xoonips/detail.php?koara_id=AN00069296-2005060 } \\
\text { 2-0016 }\end{array}$ \\
\hline
\end{tabular}

慶應義塾大学学術情報リポジトリ(KOARA)に掲載されているコンテンツの著作権は、それぞれの著作者、学会または出版社/発行者に帰属し、その権利は著作権法によって 保護されています。引用にあたっては、著作権法を遵守してご利用ください。

The copyrights of content available on the KeiO Associated Repository of Academic resources (KOARA) belong to the respective authors, academic societies, or publishers/issuers, and these rights are protected by the Japanese Copyright Act. When quoting the content, please follow the Japanese copyright act. 


\section{A novel mechanism for imatinib mesylate (STI571) resistance in CML cell line KT-1 : Role of TC-PTP in modulating signals downstream from the BCR-ABL fusion protein. \\ （慢性骨髄性白血病細胞株KT-1における新たなイマチニブ（STI571）而性化の機構： BCR-ABL融合蛋白下流のシグナル伝達を修飾するTC-PTPの役割）}

\section{清 水 孝 恒}

\section{内容の要旨}

[背景・目的］ $\mathrm{ABL}$ キナーゼの特異的阻害薬であるイマチニブ （STI571）は慢性期の慢性骨髄性白血病（CML）の第一選択薬として 定着したが、その耐性症例は臨床的に問題である。我々はイマチニブ 感受性CML細胞株KT-1より、イマチニブ耐性株KTRを樹立した。p糖 タンパクの発現、bcr-ablキメラ遺伝子の増幅、ABLキナーゼのATP結 合領域の点変異を検討したが、いずれもKTR細胞のイマチニブ而性化 の機序には関与していなかった。脱リン酸化酵素の中で、TC-PTPの著 明な発現低下を認めたため、イマチニブ而性獲得におけるTC-PTPの 意義について検討した。

[方法］KTR細胞に、TC-PTPのnuclear isoformであるTC45遺伝子と酵 素活性を持たないTC45-D182A遺伝子をレトロウィルスにより導入し た。MTTアッセイによりイマチニブに対する感受性を検討し、ウェス タンブロット法によりシグナル伝達経路を解析した。

[結果] MTTアッセイでは、KTR-TC45細胞は0.2、0.5、1 1 MのSTI571 暴露により $37 、 74.2 、 89.3 \%$ の増殖抑制を認め、イマチニブに対する感 受性を回復した。一方KTR-mock、KTR-D182A細胞では感受性の回復 は見られなかった。flow cytometerを用いたapoptosis細胞の検討では、 $0.5 \mu \mathrm{M}$ のイチニブ刺激により、TC45導入細胞では、12\%から $56 \%$ ま で増加し、アポトーシス誘導効果の回復を認めた。イマチニブ刺激に よる細胞内シグナル伝達機構について検討したところ、KTR-TC45細

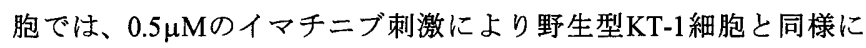
STAT5のリン酸化は完全に抑制された。一方、耐性を維持したKTRmock、KTR-D182A細胞では、親株KTR細胞と同様にSTAT5のリン酸化 は六進しており刺激後もリン酸化が維持された。JAK2、BCR-ABLの リン酸化は遺伝子導入株間での差異は見られなかった。また、BCRABLの下流にあるPKB/AKT、JNK、ERK1/2の活性化状態を遺伝子導入 株間で比較したが、差異は認められなかった。TC-PTPのmRNAの発現 を半定量PCR法で比較したところ、親株KT-1と比べKTR細胞で低下が みられ、TC-PTPの蛋白発現の低下はmRNAレベルであることが示唆 された。

[結語］KTR細胞のイマチニブ耐性化にはTC-PTPの発現低下による STAT5のリン酸化え進が関与していた。脱リン酸化酵素TC-PTPの発 現低下は、CML細胞がイマチニブへの耐性化を獲得する新たな分子 機構となり得る可能性が示唆された。

\section{論文審査の要旨}

ABLの特異的チロシンキナーゼ阻害薬であるイマチニブは慢性骨 髄性白血病 (CML) の治療薬であるが、治療中の耐性化獲得が臨床 上問題となっており、耐性化機構の解明は重要である。これまで に、bcr-abl遺伝子の増幅、bcr-abl遺伝子のキナーゼ領域の点突然変 異、多剤耐性遺伝子産物の発現などが機序として報告されているが 不明な点も多い。CML細胞株KT-1から樹立されたイマチニブ耐性 KTR細胞には、既知の機序とは異なる耐性化機構の存在が示唆さ れ、親株に比較してKTR細胞で発現が低下しているT cell protein tyrosine phosphatase (TC-PTP) に注目した。本研究において、TCPTPを再構筑することにより、KTR細胞のSTAT5リン酸化妄進が抑 えられ、イマチニブ感受性を回復することを示し、TC-PTPの発現低 下がイマチニブの新たな耐性化機構となり得ることを示晙した。

審查において、本研究で解明された耐性化機構が実際のイマチニ ブ耐性患者の中でどの程度存在するかがたずねられた。この点に関 して、非常に重要な問題であると認識しているが本邦では欧米に比 較し現在、耐性患者の検体が得られにくく解析することが困難であ ることが述べられた。また他の脱リン酸化酵素の発現低下がイマチ ニブ耐性化に関与するとの学会報告が引用され、TC-PTPの発現低下 が実際に耐性に関与する可能性惊いと回答された。患者検体を用 いた検討は今後の課題とされた。次に、KTR細胞のイマチニブ耐性 化の程度が他の耐性株の報告より弱いことが指摘された。この点に 関して、これまでの報告では本研究と異なる耐性化機構が上げられ ており、耐性化の程度の差異は耐性化機構の差異によるのではない かと回答された。またTC-PTPがSTAT5を直接の基質としているかが たずねられた。直接の証明はなされておらず報告により意見が割れ ているが、本研究においてTC-PTPとSTAT5の共沈を確認しており基 質となる可能性を強く示唆すると回答した所、実際に結果を提示し その点により踏み込むと興味梁かったとの助言があった。その他、 $\mathrm{p}$ 糖タンパクの発現六進はKTR細胞のイマチニブ耐性化には関与しな いとベラパミルの阻害実験により結論したが、サイクロスポリンな ど別の阻害薬を試みるべきであるとの指摘、更に増殖抑制効果の解 析ではMTT解析だけでなく実際の細胞数の推移を示すべきであると の指摘があった。また、BCR-ABL下流のシグナル解析に関しては、 $\mathrm{AKT} 、 \mathrm{NK} 、 \mathrm{ERK}$ 以外の検証も要すると指摘された。

以上のように、本研究では特に患者検体の解析も含め、さらなる検 討を要する点が課題として残されてはいるものの、分子標的治療薬の 新しい耐性化機構の発見が新規性として認められ、臨床へのフィード バックの可能性と併せて有意義な研究であると評価された。

論文審査担当者 主查 内科学 池田 康夫

先端医科学 河上 裕 発生- 分化生物学 須田 年生

薬剤学 谷川原祐介

学力確認担当者 :

審査委員長 : 河上 裕 